Article

\title{
Key Factors for Involvement Degree and Perceived Value in Consumers' Purchase Intention in Unpacked Stores
}

\author{
Jui-Che Tu ${ }^{1}$, Ting-Yun Lo ${ }^{1} * * \mathbb{D}$, Yi-Jing Sie ${ }^{1}$ and Tsai-Feng Kao ${ }^{2}$ \\ 1 Graduate School of Design, National Yunlin University of Science \& Technology, Douliu City 640301, Taiwan; \\ tujc@yuntech.edu.tw (J.-C.T.); aquariussie0127@gmail.com (Y.-J.S.) \\ 2 School of Arts, Minnan Normal University, Zhangzhou 363000, China; g9730808@gmail.com \\ * Correspondence: wendy0901@yahoo.com.tw
}

check for updates

Citation: Tu, J.-C.; Lo, T.-Y.; Sie, Y.-J.;

Kao, T.-F. Key Factors for Involvement Degree and Perceived Value in Consumers' Purchase Intention in Unpacked Stores. Sustainability 2021, 13, 12563. https://doi.org/10.3390/ su132212563

Academic Editor: Andrea Pérez

Received: 30 October 2021

Accepted: 11 November 2021

Published: 13 November 2021

Publisher's Note: MDPI stays neutral with regard to jurisdictional claims in published maps and institutional affiliations.

Copyright: (C) 2021 by the authors. Licensee MDPI, Basel, Switzerland. This article is an open access article distributed under the terms and conditions of the Creative Commons Attribution (CC BY) license (https:// creativecommons.org/licenses/by/ $4.0 /)$.

\begin{abstract}
The Taiwanese government has decided to reduce the use of disposable plastics in response to the European Union's announcement of the Circular Economy Action Plan. With the circular economy becoming a sustainable development trend, consumers have become the latter and the environment's lifeblood. There has been a wave of unpacked stores around the world in recent years, encouraging consumers to reduce the use of plastics and bring their own bags or containers when shopping, thereby reducing the waste of resources. This research adopted qualitative and quantitative research methods to verify the model of involvement degree and perceived value on consumers' purchase intentions in unpacked stores through expert interviews and structural equations and extract the key factors for promoting unpacked stores. The research results show that the three dimensions of involvement degree will indirectly affect consumers' purchase intentions through the four dimensions of perceived value. Perceived value plays a mediating role between the involvement degree and purchase intention. Unpacked stores can be used to promote industry characteristics and image, and unpacked consumption thinking can be advanced through the Internet, education, or lectures based on community development. In this way, unpacked stores can be instilled in people's psychological value.
\end{abstract}

Keywords: unpacked stores; involvement degree; perceived value; purchase intention; circular economy

\section{Introduction}

Nowadays, plastic products have caused great pollution to the ecological environment. People's desire for temporary convenience-for instance, using "plastic packaging"—has caused irretrievable damage to the earth's environment. Plastics are classified as nonrecyclable objects in waste classification and must be disposed of through landfills or incineration. If they are disposed of through landfills, the decomposition time is about 100 years or more. Meanwhile, incineration produces dioxin and various harmful substances in the process of chlorination, disinfection, and bleaching components [1-4]. The purpose of the packaging itself is to protect the product. However, in their attempts to make the product look attractive, people resorted to excessive packaging, leading to a waste of resources - an issue people should take into consideration [5-9].

In 2012, the European Union signed the "Manifesto for a Resource-Efficient Europe", stating that it had no choice but to move towards a circular economy. Further, in 2015, it released the "Circular Economy Action Plan" to put forward specific strategies and action plans for zero waste goals and set a clear schedule $[5,10,11]$. On the other hand, the United Nations also adopted 17 Sustainable Development Goals (SDGs). Countries have implemented many related policies, designed various ways to increase the recycling rate, and implemented reduced packaging and other practices to guide people in changing their consumption and living habits.

Through the community-type unpackaged store, In.gredients, in Austin, United States, which combines the community garden and bar, people can realize zero-waste by directly 
purchasing goods in the store, and they can also enjoy the coolness and drink beer in the store; the Iceland supermarket in the United Kingdom proposed to completely remove the plastic packaging of its private-label commodities by 2023; Germany also launched a buying campaign in unpacked stores in 2014 to promote a whirlwind for unpacked stores; more plastic-free supermarkets are also appearing in Thailand, Vietnam, and other places; UnPackt consumers in Singapore can calculate the price based on the weight of the goods they buy, saving the consumables on the packaging; Taiwan Cat Hotel Green Web also sells unpackaged cat supplies and provides refilled cat litter. It offers containers to first-time consumers, which the latter can bring to the store for reuse at their next shopping trip [12-23].

At present, the past research does not have an in-depth discussion on unpacked stores. Thus, this research mainly used two dimensions of involvement degree and perceived value, combined with structural equation modeling analysis. The involvement degree is the level of concern or interest shown during the purchasing process [24-27]; hence, related to a particular purchase. Meanwhile, the perceived value means that the higher the consumer's perception of the product, the higher their purchase intentions. Conversely, the higher the consumers' perceived risk in the purchase decision-making process, the easier it is to hinder their purchase intentions [28-31]. Therefore, this research intended to explore the relationship between consumers and unpacked stores to extract the key factors affecting consumers' purchase intentions and provide a direction and guidelines for developing unpacked stores in the future. The structure of this research is shown in Figure 1.

The research objectives are as follows:

- Discuss the current environmental management issues facing unpacked stores;

- Understand the development context and dimensions of unpacked stores through expert interviews;

- Explore the model relationship between the involvement degree and the perceived value of consumers' purchase intentions in unpacked stores through structural equation modeling;

- Explore the relationship and influencing factors of the involvement degree on the perceived value;

- Develop the elements of promoting and marketing unpacked stores by operators in the future;

\subsection{Research Dimensions}

\subsubsection{Involvement Degree}

Zaichkowsky divided the attributes of involvement into (1) involvement with products: consumers' interest in products, needs, and values, and other behaviors that affect purchase intention; (2) involvement with advertisements: the consumer's stimulation by information, advertising messages, etc. that affect purchase intention; (3) involvement with purchase decisions: the higher the consumers' involvement in price comparison or collection of relevant information, the higher the level of purchase involvement. Noteworthily, these three involvement attributes are subject to the influence of personal, product, and situational factors.

Zaichkowsky developed the "Personal Involvement Inventory" (PII). This scale is used to evaluate the degree of consumer involvement, which is divided into the dimensions of need, interest, and value [32,33]. However, he believed that the PII scale lacks accuracy and is difficult to measure directly. Thus, Zaichkowsky later revised the PII scale to the RPII (Revised Personal Involvement Inventory). Consequently, the reliability and validity of this scale have become sufficient, as proven in the tests [34]. Therefore, this research used the RPII scale published by Zaichkowsky for the question items on the involvement degree in the questionnaire. 


\subsubsection{Perceived Value}

Sweeney and Soutar divided perceived value into four dimensions, as follows: (1) Emotional value, which refers to the emotional feelings that consumers have through product consumption, such as pleasure, desire, and affection; (2) Quality value, which implies that consumers' cognition of quality expectations is in line with their expected expectations, such as product materials, product functions, etc.; (3) Social value, which refers to the effect that products bring to consumers to improve or self-practice in the social system, such as social status, identification, reputation, etc.; (4) Price value, which refers to the utility brought by short-term or long-term costs as perceived by consumers, such as being cheap, expensive, etc. [35]. The concept of perceived value is shown in Figure 2 [28].

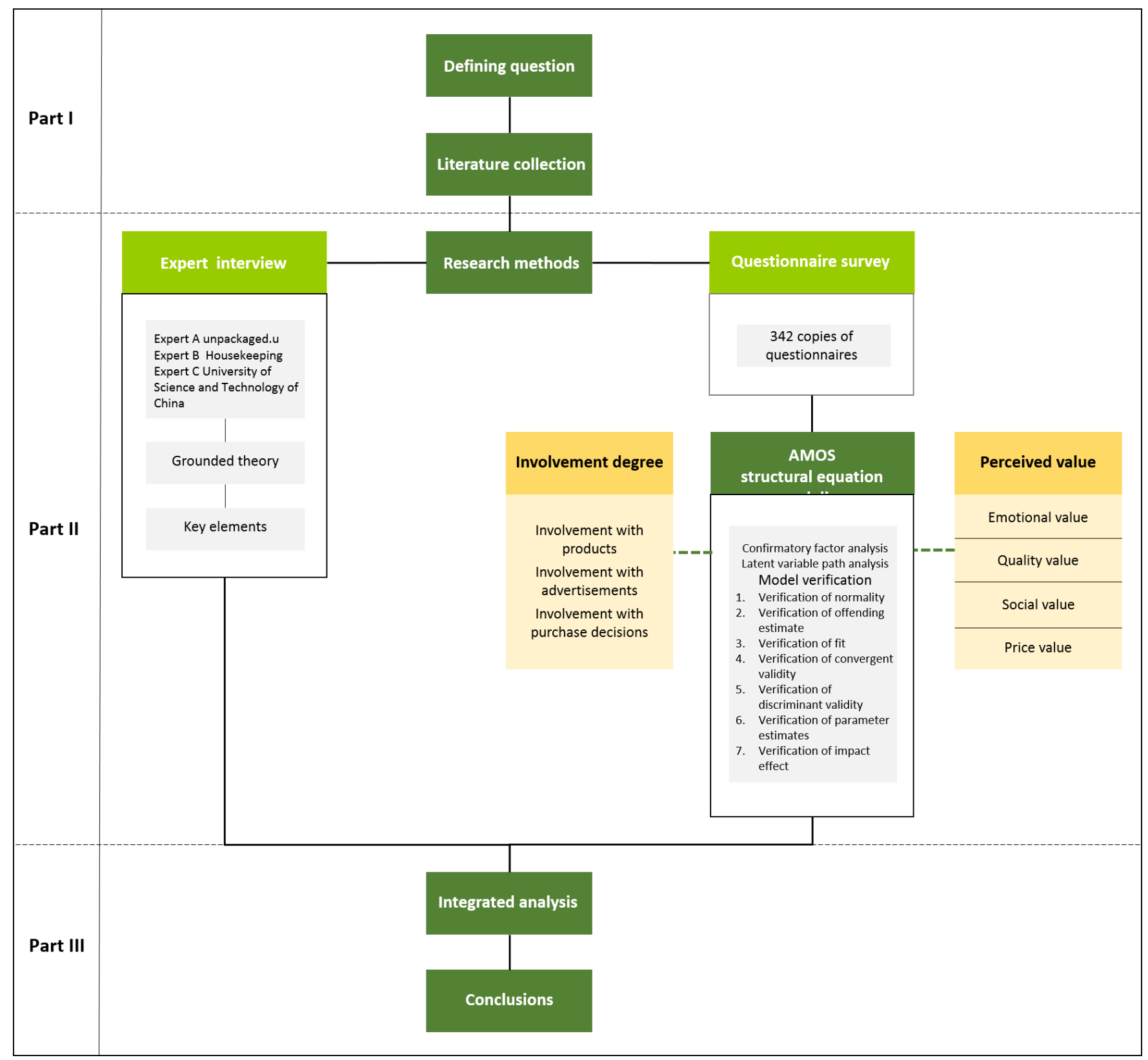

Figure 1. Research Structure. 


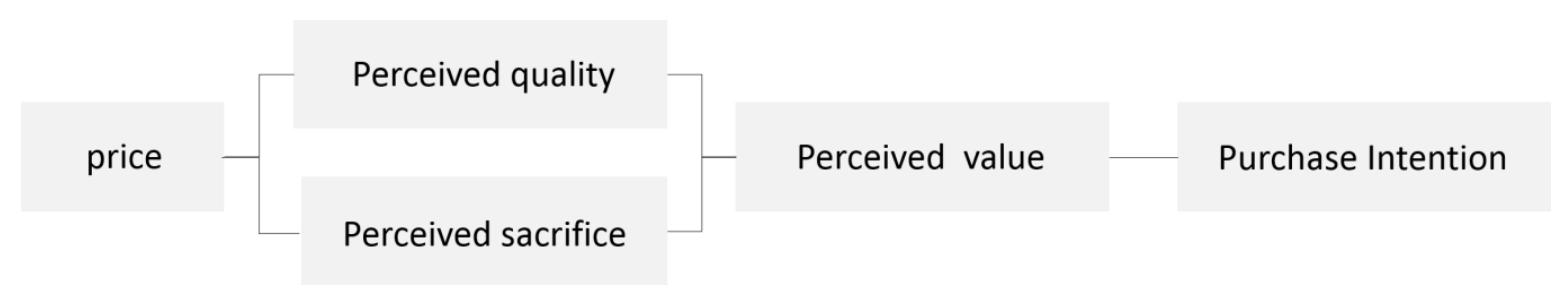

Figure 2. Concept Model of Perceived Value.

\section{Materials and Methods}

\subsection{Expert Review Method}

The interviewees of the experts in this research included staff from unpacked stores and experts and scholars on consumer psychology and the promotion of ecological conservation issues, as shown in Table 1. Through in-depth interviews with academic and industrial experts, professional knowledge and information were extracted to understand the impacts of unpacked stores on consumers and environmental conservation. The grounded theory was used to convert the verbatim manuscript into open coding, main axis coding, and selective coding based on the suggestions provided by the experts, as shown in Table 2, which are the key elements summarized by the experts and are used as a reference for the dimension items of the questionnaire [36-39].

Table 1. Information of interviews.

\begin{tabular}{cccc}
\hline Number & Interviewee & Organization & Relevant Experience/Research Field \\
\hline A & Huang, founder & Unpacked store-unpackaged.u & Founder of the store, unpackaged.u \\
\hline B & Yang, founder & $\begin{array}{c}\text { Sustainable Grocery } \\
\text { Store-Housekeeping }\end{array}$ & Founder of Housekeeping \\
\hline C & $\begin{array}{c}\text { Huang, } \\
\text { Assistant Professor }\end{array}$ & $\begin{array}{c}\text { Department of Communication Design } \\
\text { China University of Technology }\end{array}$ & $\begin{array}{l}\text { User and consumer psychology, creative marketing, } \\
\text { content marketing, cultural and creative business } \\
\text { management, innovation, and entrepreneurship }\end{array}$ \\
\hline
\end{tabular}

Table 2. Key Elements Summarized by Experts.

\begin{tabular}{|c|c|c|}
\hline & Key Outline & Elements Summarized \\
\hline 1 & $\begin{array}{c}\text { Features of } \\
\text { unpacked stores }\end{array}$ & $\begin{array}{l}\text { - The product categories are different from those of ordinary supermarkets. } \\
\text { - } \quad \text { Consumers are encouraged to bring their own containers when buying. } \\
\text { - They provide another mode of consumption. } \\
\text { - The feeling of integrating experience elements. }\end{array}$ \\
\hline 2 & Problems faced & $\begin{array}{l}\text { - The concept of ecological conservation is just a way to buy goods. } \\
\text { - It is difficult to compete with the product prices of general supermarkets. } \\
\text { - Relevant measures need to be formulated through the government and } \\
\text { non-governmental organizations. }\end{array}$ \\
\hline 3 & Consumer demand & $\begin{array}{l}\text { - } \quad \text { Product quality should be good. } \\
\text { - } \quad \text { More styles should be provided for a single product. } \\
\text { - } \quad \text { Consumers can buy the needed quantity. }\end{array}$ \\
\hline 4 & $\begin{array}{l}\text { Promotion elements for } \\
\text { unpacked stores }\end{array}$ & $\begin{array}{l}\text { - Diversified products for consumers to choose from. } \\
\text { - } \quad \text { Consumers can purchase the quantity for their demand and consume with less pressure. } \\
\text { - The cost of the container is converted to a discounted price. } \\
\text { - } \quad \text { The quality of the goods sold is good, and an inspection report is attached. } \\
\text { - The efficiency of transmission through the network is the most direct and fastest. } \\
\text { - } \quad \text { Begin with the development of small supermarkets in the community. } \\
\text { - The introduction of ecological conservation policies is beneficial to future developments. } \\
\text { - The consumer's mood is improved after a purchase is made. }\end{array}$ \\
\hline
\end{tabular}


The questionnaire was divided into a pre-test and a formal test, and the five-point Likert scale was used for measurement. The test subjects were consumers over 18 years old, and the questionnaires were sent online. The RPII scale published by Zaichkowsky was adopted as the reference for the questionnaire items for the involvement degree [34]. The third questionnaire item is the reverse question. The four dimensions developed by Sweeney and Soutar, namely emotional value, quality value, social value, and price value, were used as the reference for the items of the perceived value in this research [35]. In total, 30 subjects were asked to take the pre-test. One item of the involvement degree was deleted via the reliability analysis. After the deletion, there were 9 items for the involvement degree, 12 items for the perceived value, and 3 items for the purchase intention. A total of 342 subjects participated in the formal test, and the questionnaire items are shown in Tables 3 and 4 [40].

Table 3. Sociodemographic Characteristics.

\begin{tabular}{ll}
\hline Region & Taiwan \\
\hline Age & over $18(19-2528 \% ; 26-3514 \% ; 36-4523 \%$; Over 46 28\%) \\
\hline People (N) & 342 (male 45\% female 55\%) \\
\hline Education & below high school 20\%; university 35\%; above graduate school 45\% \\
\hline Marital & married 44\%; unmarried 56\% \\
\hline Salary (month) & below 10,000 18\%; 10,000-30,000 29\%; 30,000-60,000 39\%; over $60,00014 \%$ \\
\hline Questionnaire & on-lines, social-media channels \\
\hline
\end{tabular}

Table 4. Questionnaire Survey.

\begin{tabular}{cc}
\hline (1) Involvement degree \\
\hline a1 & I think it is important to buy goods at an unpacked store. \\
\hline a2 & I think it is interesting to buy goods at an unpacked store. \\
\hline a3 & I think it is exciting to buy goods at an unpacked store. \\
\hline a4 & I think it means a lot to me to buy goods at an unpacked store. \\
\hline a5 & I think it is appealing to buy goods at an unpacked store. \\
\hline a6 & I think it is fascinating to buy goods at an unpacked store. \\
\hline a7 & I think it is valuable to buy goods at an unpacked store. \\
\hline a8 & I think it is engaging to buy goods at an unpacked store. \\
\hline a9 & I think it is needed to buy goods at an unpacked store. \\
\hline (2) Perceived value \\
\hline Emotional value \\
\hline b1_1 & I think it feels great to buy goods at an unpacked store. \\
\hline b1_2 & I think it will bring me a pleasant feeling if I buy goods at an unpacked store. \\
\hline b1_3 & I think I will take the initiative to buy goods at an unpacked store if I need to buy something. \\
\hline Quality value \\
\hline b2_1 & I think the quality of the goods provided by unpacked stores is excellent. \\
\hline b2_2 & I think the quality of the goods provided by unpacked stores is above a certain level. \\
\hline b2_3 & I think the quality of the goods provided by unpacked stores is stable. \\
\hline Social value \\
\hline b3_1 & I think it will improve my social status if I buy goods at an unpacked store. \\
\hline b3_3 & I think it will enhance my distinctive image if I buy goods at an unpacked store. \\
\hline
\end{tabular}


Table 4. Cont.

\begin{tabular}{ll}
\hline \multicolumn{1}{l}{ Price value } \\
\hline b4_1 & I think the prices of the goods sold in unpacked stores are reasonable. \\
\hline b4_2 & $\begin{array}{l}\text { I think that if I buy goods at an unpacked store, the cost-effectiveness would be in line } \\
\text { with my expectations. }\end{array}$ \\
\hline b4_3 & I think it is worth the money if I buy goods at an unpacked store. \\
\hline (3) Purchase intention \\
\hline c3_1 & I am willing to go to unpacked stores to buy goods. \\
\hline c3_2 & I will give priority to shopping at unpacked stores when I need to buy something. \\
\hline c3_2 & I am willing to recommend unpacked stores to others. \\
\hline
\end{tabular}

\subsection{Structural Equation Modeling}

Structural Equation Modeling (SEM) is a multivariate statistical technology that combines factor analysis and path analysis to quantitatively study the interaction among multiple variables. In the past 30 years, SEM has been widely used in the field of social sciences and behavioral sciences, and it has been gradually applied to consumer market research in recent years. The model includes two types of variables. One type is structural variables, which cannot be directly observed, also known as latent variables and represented by ellipses. The other type is observation variables, which can be obtained through questionnaires or interviews and are represented by rectangles [41].

Purchase intention is the customer's perception of whether the product or service meets his expectations to demonstrate purchase behavior. SEM, whose purpose is to explore the causal relationship between the dimensions, can be a modeling method used to study purchase intention. This research used SEM as the main research method to explore the influence factors of the involvement degree and perceived value on consumers' purchase intention in unpacked stores is shown in Figure 3. An analysis of the complete causality of the structural model is shown in Section 3: Results.

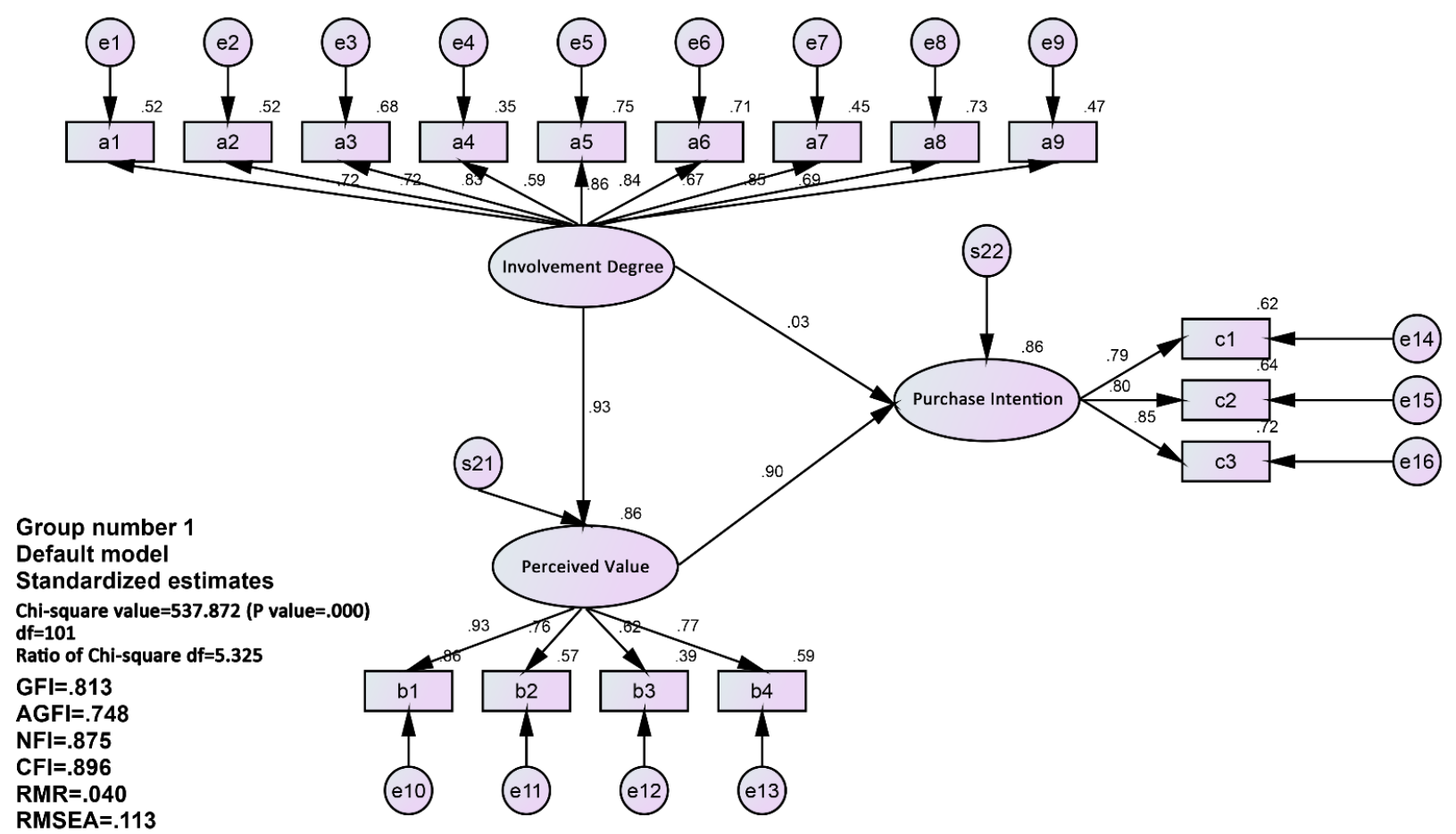

Figure 3. Latent Variable Path Analysis. 
The research hypotheses of this structural model are as follows, as shown in Figure 4:

$\mathrm{H} 1$

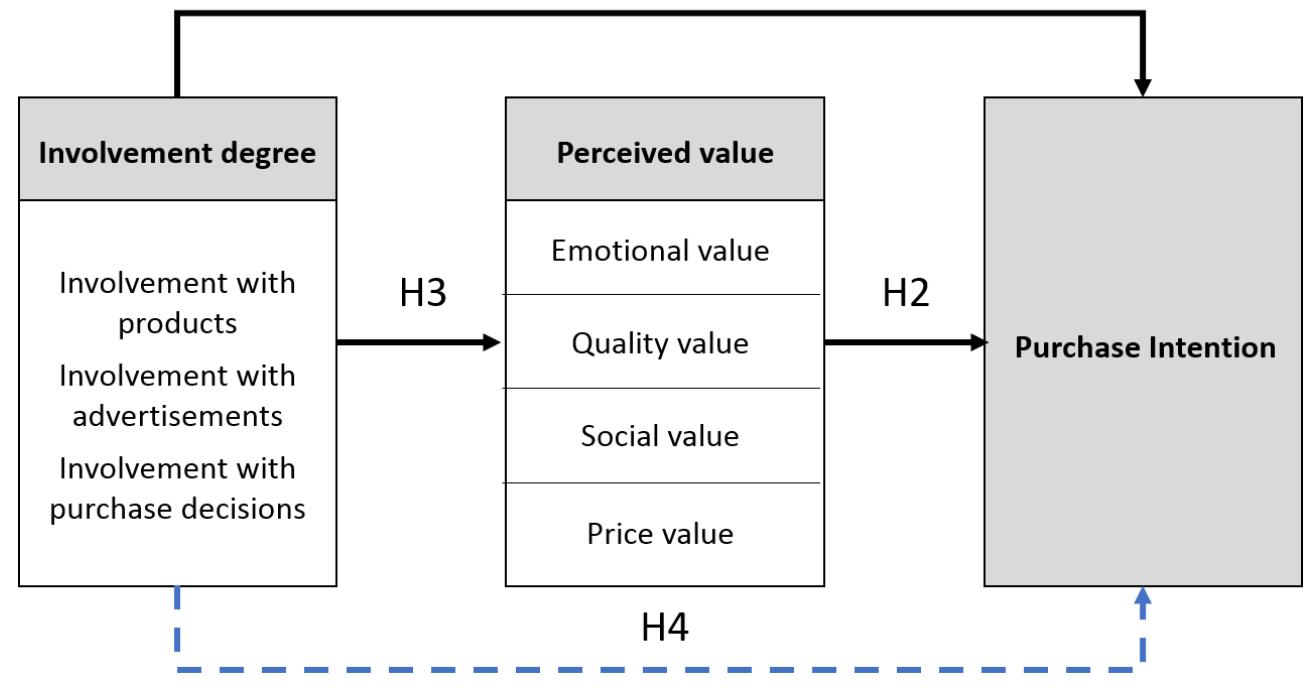

Figure 4. Research Hypotheses.

Hypothesis 1. Involvement degree has a significant impact on purchase intention.

Hypothesis 2. Perceived value has a significant impact on purchase intention.

Hypothesis 3. Involvement degree has a significant impact on perceived value.

Hypothesis 4. Involvement degree has an indirect and significant impact on purchase intention through perceived value.

\section{Results}

\subsection{Verification of Normality}

In this model, it can be found that the absolute values of the skewness $(-0.987-0.157)$ and kurtosis (-0.584-1.911) of all the observed variables (items) are less than 2. Thus, the observed variables in this research can be considered to have univariate normality. Secondly, the Mardia coefficient of the involvement degree, perceived value, and purchase intention are 219.130, and $p(p+2)$ is 624, which are both significantly larger than the Mardia coefficient. Therefore, it can be asserted that the sample data has multiple normalities [42-45].

Furthermore, it can be analyzed from the above verification that this model conforms to the multiple normalities. Therefore, the maximum likelihood estimation method can be used to verify the model fit. Refer to the confirmatory factor analysis table.

\subsection{Verification of Offending Estimate}

Observing the structure model parameter estimation table, the variance of the error is between 0.082-0.401, all positive; the standardized regression weighting coefficient is between 0.028-0.930, and there is no phenomenon greater than 0.95; the standard error is between $0.102-0.391$, the standardized regression weighting coefficient is between $0.028-0.930$, and there is a minimal standard error.

It can be analyzed from the above verification that the structural model does not have the problem of offending estimates. Refer to the parameter estimation table.

\subsection{Verification of Fit}

As shown in the fit index verification table, we can determine from the absolute goodness-of-fit index that the chi-square value of the measurement model is 136.980 , and 
the probability $p$ is 0.000 , which is less than 0.05 . Except that the chi-square value has not passed the standard of an acceptable model, all other indices meet the passing standards.

The chi-square value concerned is usually greatly affected by the number of samples. Hence, scholars believe that paying too much attention to this index is unnecessary, and it can even be replaced by the chi-square degree of freedom ratio. This model's chi-square degree of freedom ratio is 1.356 , in line with the standard value. From the perspective of the absolute goodness-of-fit indices, incremental fit indices, and parsimony fit indices, all indices meet the standard of good fit.

It can be analyzed from the above verification that all indices of the structural model after the Bollen-Stine Bootstrap revision have reached the level of academic requirements. Hence, overall, it shows that this model is a model of good fit. Refer to the verification of fit indices in Table 5.

Table 5. Verification of Fit Indices.

\begin{tabular}{|c|c|c|c|c|c|}
\hline Statistical Verifi & tion Value & $\begin{array}{l}\text { Standard } \\
\text { Value }\end{array}$ & $\begin{array}{l}\text { Original } \\
\text { Result }\end{array}$ & $\begin{array}{c}\text { Bootstrap } \\
\text { Corrected Result }\end{array}$ & Fit Judgment \\
\hline \multirow{7}{*}{$\begin{array}{c}\text { Absolute } \\
\text { goodness-of-fit indices }\end{array}$} & $\chi^{2}(p \geq \alpha$ value $)$ & $\begin{array}{l}\text { The smaller, } \\
\text { the better }\end{array}$ & $\begin{array}{c}537.872 \\
(p=0.000)\end{array}$ & $\begin{array}{c}136.980 \\
(p=0.000)\end{array}$ & Not meeting the standard value \\
\hline & $x^{2} / \mathrm{df}$ & $<3$ & 5.325 & 1.356 & Meeting the standard value \\
\hline & GFI & $>0.9$ & 0.813 & 0.953 & Meeting the standard value \\
\hline & AGFI & $>0.9$ & 0.748 & 0.936 & Meeting the standard value \\
\hline & RMR & $<0.08$ & 0.040 & 0.040 & Meeting the standard value \\
\hline & SRMR & $<0.08$ & 0.057 & 0.057 & Meeting the standard value \\
\hline & RMSEA & $<0.08$ & 0.113 & 0.032 & Meeting the standard value \\
\hline \multirow{5}{*}{$\begin{array}{c}\text { Incremental } \\
\text { goodness-of-fit indices }\end{array}$} & NFI & $>0.9$ & 0.875 & 0.968 & Meeting the standard value \\
\hline & NNFI & $>0.9$ & 0.876 & 0.990 & Meeting the standard value \\
\hline & CFI & $>0.9$ & 0.896 & 0.991 & Meeting the standard value \\
\hline & RFI & $>0.9$ & 0.852 & 0.962 & Meeting the standard value \\
\hline & IFI & $>0.9$ & 0.896 & 0.991 & Meeting the standard value \\
\hline \multirow{3}{*}{$\begin{array}{c}\text { Parsimony } \\
\text { goodness-of-fit indices }\end{array}$} & PNFI & $>0.5$ & 0.737 & 0.815 & Meeting the standard value \\
\hline & PGFI & $>0.5$ & 0.604 & 0.707 & Meeting the standard value \\
\hline & $\mathrm{CN}$ & $>200$ & 80 & 313 & Meeting the standard value \\
\hline
\end{tabular}

\subsection{Verification of Convergent Validity}

Observing the confirmatory analysis table of the measurement model, we found that the standardized regression weighting coefficients of all items are greater than 0.5 , falling between 0.595 and 0.932 , and the $t$ value is greater than 1.96; hence, they are all significant. Further, the composite reliability of each sub-dimension is in the range of 0.855-0.924 and greater than 0.6 , and the average variation extraction of each sub-dimension is greater than 0.5 between $0.590-0.802$.

It can be analyzed from the above verification that the dimensions of the involvement degree, perceived value, and purchase intention can all meet the requirements of convergent validity. Therefore, the internal quality of the measurement model is quite good. Refer to the confirmatory factor analysis in Table 6 . 
Table 6. Confirmatory Factor Analysis.

\begin{tabular}{|c|c|c|c|c|c|c|c|c|c|c|c|c|}
\hline Dimension & $\begin{array}{c}\text { Observed } \\
\text { Variable }\end{array}$ & $\mathbf{M}$ & SD & SK & KU & SFL(t) & SE & SMC & EV & $\alpha$ & CR & AVE \\
\hline \multirow{10}{*}{$\begin{array}{c}\text { Involvement } \\
\text { degree }\end{array}$} & $\begin{array}{c}\text { Involvement } \\
\text { degree }\end{array}$ & & & & & & & & & \multirow{10}{*}{0.923} & 0.895 & 0.590 \\
\hline & a1 & 3.839 & 0.863 & -0.643 & 0.816 & $0.714(14.994) *$ & 0.184 & 0.510 & 0.364 & & & \\
\hline & $\mathrm{a} 2$ & 4.009 & 0.764 & -0.924 & 1.767 & $0.73(15.464)^{*}$ & 0.161 & 0.533 & 0.271 & & & \\
\hline & a3 & 3.640 & 0.858 & -0.217 & -0.043 & $0.828(18.562) *$ & 0.171 & 0.685 & 0.231 & & & \\
\hline & $\mathrm{a} 4$ & 4.199 & 0.786 & -1.055 & 1.911 & $0.595(11.837)^{*}$ & 0.176 & 0.354 & 0.398 & & & \\
\hline & a5 & 3.713 & 0.890 & -0.659 & 0.519 & $0.863(19.816) *$ & 0.173 & 0.744 & 0.202 & & & \\
\hline & a6 & 3.558 & 0.850 & -0.226 & 0.113 & $0.843(19.084)^{*}$ & 0.168 & 0.711 & 0.208 & & & \\
\hline & a7 & 4.029 & 0.795 & -0.858 & 1.440 & $0.672(13.82) *$ & 0.173 & 0.452 & 0.346 & & & \\
\hline & a8 & 3.556 & 0.881 & -0.221 & 0.159 & $0.849(19.348) *$ & 0.173 & 0.722 & 0.215 & & & \\
\hline & a9 & 3.833 & 0.838 & -0.368 & 0.027 & $0.685(14.17)^{*}$ & 0.181 & 0.470 & 0.371 & & & \\
\hline \multirow{16}{*}{$\begin{array}{l}\text { Perceived } \\
\text { value }\end{array}$} & $\begin{array}{c}\text { Emotional } \\
\text { value }\end{array}$ & & & & & & & & & \multirow{4}{*}{0.835} & 0.857 & 0.668 \\
\hline & b1_1 & 3.798 & 0.776 & -0.466 & 0.615 & $0.857(19.223) *$ & 0.154 & 0.735 & 0.159 & & & \\
\hline & b1_2 & 3.693 & 0.812 & -0.407 & 0.574 & $0.84(18.547) *$ & 0.164 & 0.706 & 0.193 & & & \\
\hline & b1_3 & 3.535 & 1.006 & -0.512 & -0.180 & $0.751(15.816)^{*}$ & 0.213 & 0.563 & 0.441 & & & \\
\hline & $\begin{array}{l}\text { Quality } \\
\text { value }\end{array}$ & & & & & & & & & \multirow{4}{*}{0.921} & 0.924 & 0.802 \\
\hline & b2_1 & 3.576 & 0.886 & -0.180 & -0.109 & $0.856(19.413) *$ & 0.174 & 0.732 & 0.210 & & & \\
\hline & b2_2 & 3.553 & 0.942 & -0.289 & -0.210 & $0.932(22.412) *$ & 0.175 & 0.869 & 0.116 & & & \\
\hline & b2_3 & 3.544 & 0.927 & -0.195 & -0.339 & $0.897(20.995)$ * & 0.177 & 0.804 & 0.168 & & & \\
\hline & Social value & & & & & & & & & \multirow{4}{*}{0.899} & 0.899 & 0.748 \\
\hline & b3_1 & 2.959 & 1.052 & 0.157 & -0.493 & $0.854(18.983) *$ & 0.211 & 0.730 & 0.298 & & & \\
\hline & b3_2 & 3.202 & 1.090 & -0.134 & -0.584 & $0.872(19.686)^{*}$ & 0.216 & 0.760 & 0.284 & & & \\
\hline & B3_3 & 3.266 & 1.046 & -0.177 & -0.523 & $0.869(19.522) *$ & 0.208 & 0.754 & 0.268 & & & \\
\hline & Price value & & & & & & & & & \multirow{4}{*}{0.909} & 0.909 & 0.769 \\
\hline & b4_1 & 3.480 & 0.859 & 0.077 & -0.244 & $0.846(18.983) *$ & 0.171 & 0.716 & 0.209 & & & \\
\hline & b4_2 & 3.558 & 0.860 & -0.098 & -0.372 & $0.873(19.969) *$ & 0.168 & 0.762 & 0.176 & & & \\
\hline & b4_3 & 3.523 & 0.834 & -0.105 & 0.173 & $0.91(21.389)$ * & 0.158 & 0.828 & 0.119 & & & \\
\hline \multirow{5}{*}{$\begin{array}{l}\text { Purchase } \\
\text { intention }\end{array}$} & $\begin{array}{l}\text { Purchase } \\
\text { intention }\end{array}$ & & & & & & & & & \multirow{4}{*}{0.850} & 0.855 & 0.663 \\
\hline & c1 & 3.930 & 0.789 & -0.987 & 1.775 & $0.792(16.997) *$ & 0.164 & 0.628 & 0.231 & & & \\
\hline & c2 & 3.582 & 0.968 & -0.563 & 0.005 & $0.795(17.07) *$ & 0.201 & 0.633 & 0.343 & & & \\
\hline & c3 & 3.857 & 0.828 & -0.813 & 1.134 & $0.855(19.036) *$ & 0.166 & 0.730 & 0.184 & & & \\
\hline & Mardia & & & & 219.130 & & & $p(p+2$ & $=624$ & 0.962 & & \\
\hline
\end{tabular}

* is significant when it is $0.05 ; \mathrm{M}$ is the mean; $\mathrm{SD}$ is the standard deviation; SK is the skewness; KU is the kurtosis; $\mathrm{SFL}(\mathrm{t})$ is the standardized regression weighting coefficient (standardized factor loading), $t$ is the value of $t$; $S E$ is the standard error of factor loading; $S M C$ is the squared multiple correlations; $\mathrm{EV}$ is the error variance; $\alpha$ is Cronbach's $\alpha$ value; $\mathrm{CR}$ is the composite reliability; AVE is the average variance extracted; $p$ is the number of observed variables.

\subsection{Verification of Discriminant Validity}

Observing the discriminant validity test table, we found the square root of the AVE of each dimension is between $0.759-0.896$, which is more than $75 \%$ and greater than the correlation coefficient between each dimension.

The analysis results show that the square root of the AVE of each dimension satisfies the judgment criterion, indicating that the scale has discriminative validity. Therefore, it again proves that the inherent quality of the measurement model is remarkable. 
It can be analyzed from the above test that in terms of the fit of the model, the standardized regression weighting coefficients of each item, the verification of the convergent validity, and the discriminant validity, the overall internal (reliability and validity) and external (fit) quality of the concept model is quite good and is suitable for structural model analysis. Furthermore, the causal relationship between the latent variables was verified. Refer to the discriminant validity test in Table 7.

Table 7. Discriminant Validity Test.

\begin{tabular}{lccccccc}
\hline \multirow{2}{*}{ Dimension } & Number of Items & \multicolumn{7}{c}{ Correlation Coefficient } \\
\cline { 3 - 8 } & & $\mathbf{A}$ & $\mathbf{B}$ & $\mathbf{C}$ & $\mathbf{D}$ & $\mathbf{E}$ & F \\
\hline Involvement degree & 9 & $\mathbf{0 . 7 5 9}$ & & & & & \\
\hline A. Emotional value & 3 & 0.966 & $\mathbf{0 . 8 1 7}$ & & & & \\
\hline B. Quality value & 3 & 0.670 & 0.712 & $\mathbf{0 . 8 9 6}$ & & & \\
\hline C. Social value & 3 & 0.565 & 0.597 & 0.622 & $\mathbf{0 . 8 6 5}$ & & \\
\hline D. Price value & 3 & 0.708 & 0.742 & 0.780 & 0.713 & $\mathbf{0 . 8 7 7}$ & \\
\hline E. Purchase intention & 3 & 0.866 & 0.889 & 0.718 & 0.567 & 0.768 & $\mathbf{0 . 8 1 5}$ \\
\hline
\end{tabular}

\subsection{Verification of Parameter Estimates}

\subsubsection{In Terms of the Involvement Degree Dimension}

In the sub-dimension of the involvement degree, the load estimate is from $0.590-0.864$, and the $t$ value is greater than 1.96, reaching a significant level. The load estimate for Item 5 , "I feel it appealing to buy goods at an unpacked store", is the maximum value of 0.864 . Its $\mathrm{R} 2$ value (SMC) is 0.746 and greater than 0.4 , which means that it has explanatory power. The R2 value (SMC) ranges from 0.348-0.746, and only the R2 value (SMC) of Item 4, "I think it means a lot to me to buy goods at an unpacked store", is 0.348 and not greater than the ideal standard of 0.4 . The explanation ability of the remaining items is very high.

The factor load of each dimension was compared, and the most important factor is Item 5, "I think it is appealing to buy goods at an unpacked store", (0.864), followed by Item 8, "I think it is engaging to buy goods at an unpacked store" (0.852), and the minimum is Item 4, "I think it means a lot to me to buy good at an unpacked store" (0.590).

From the above analysis, it is found that it is necessary to pay attention to the main key factors, such as consumers' attention and curiosity for products, to enhance consumers' awareness of the involvement degree in unpacked stores.

\subsubsection{In Terms of Perceived Value Dimension}

The perceived value dimension includes four sub-dimensions: emotional value, quality value, social value, and price value. The estimated load of emotional value is 0.925 , the highest among all the sub-dimensions. The R2 value is 0.856 and greater than 0.4 , which means it has a lot of explanatory power.

In terms of the sub-dimensions of quality value, social value, and price value, the estimated value of the load is between 0.6 and 0.7 , and the $t$ value is also greater than 1.96, reaching a significant level. In terms of $\mathrm{R} 2$, although only the social value does not reach the standard of $0.4(0.385)$, it is also very close to the ideal standard of 0.4 .

Therefore, in consumers' perception of perceived value, emotional value $(0.925)$ is the biggest key factor for consumers to perceive value, followed by price value $(0.769)$ and quality value $(0.756)$.

It is found from the above analysis that emotional value, price value, quality value, and social value are all important influencing factors in enhancing consumers' perception of the value of unpacked stores. Among them, emotional value is the most crucial to the perceived value of unpacked stores. In the future, various activities, such as education and lectures, can be used to convey the idea of unpacked consumption and emphasize the environmental damage from over packaging. 


\subsubsection{In Terms of Purchase Intention Dimension}

The purchase intention dimension includes three questionnaire items, namely "I am willing to buy goods at unpacked stores", "I will give priority to shopping at unpacked stores when I need to buy something", and "I am willing to recommend unpacked stores to others".

The load estimate of "I am willing to recommend unpacked stores to others" is 0.850 and is the highest. Meanwhile, the R2 value of 0.723 is much greater than 0.4, indicating that it has very good explanatory power.

The load estimates of the remaining two items are between 0.7 and 0.8 , and the $t$-value is also greater than 1.96, reaching a significant level. The $\mathrm{R} 2$ reaches the standard of 0.4 , indicating that it has very good explanatory power.

According to the above analysis, the three items, "I am willing to buy goods at unpacked stores", "I will give priority to shopping in unpacked stores to buy goods when I need to buy something", and "I am willing to recommend unpacked stores to others" are the main factors affecting purchase intention. Among them, "I am willing to recommend unpacked stores to others" is the most critical to consumers' purchase intention, indicating that consumers also have an inherent psychological emphasis on unpacked consumption. In the future, products, advertisements, audio, and videos can be used to promote the thinking of unpacked consumption to the public in multiple directions. Refer to the parameter estimations in Table 8.

Table 8. Parameter Estimations.

\begin{tabular}{|c|c|c|c|c|c|c|c|}
\hline Parameter & & & $\begin{array}{c}\text { Standardized } \\
\text { Regression } \\
\text { Weighting Coefficient }\end{array}$ & $\begin{array}{l}\text { Standard } \\
\text { Deviation }\end{array}$ & t Value & $\begin{array}{c}\text { Error } \\
\text { Variance }\end{array}$ & $\begin{array}{c}\text { Squared } \\
\text { Multiple } \\
\text { Correlations }\end{array}$ \\
\hline Involvement degree & $->$ & a1 & 0.720 * & 0.183 & 15.144 & 0.358 & 0.519 \\
\hline Involvement degree & $->$ & a2 & 0.724 * & 0.162 & 15.256 & 0.277 & 0.524 \\
\hline Involvement degree & $->$ & a3 & $0.826^{*}$ & 0.171 & 18.489 & 0.232 & 0.683 \\
\hline Involvement degree & $->$ & $\mathrm{a} 4$ & 0.590 * & 0.177 & 11.694 & 0.401 & 0.348 \\
\hline Involvement degree & $->$ & a5 & 0.864 * & 0.173 & 19.839 & 0.201 & 0.746 \\
\hline Involvement degree & $->$ & a6 & $0.843 *$ & 0.168 & 19.084 & 0.208 & 0.711 \\
\hline Involvement degree & $->$ & a7 & 0.668 * & 0.173 & 13.681 & 0.350 & 0.446 \\
\hline Involvement degree & $->$ & a5 & $0.852 *$ & 0.172 & 19.437 & 0.211 & 0.727 \\
\hline Involvement degree & $->$ & a9 & $0.686^{*}$ & 0.181 & 14.177 & 0.370 & 0.471 \\
\hline Perceived value & $->$ & b1 & $0.925 *$ & 0.102 & 11.302 & 0.082 & 0.856 \\
\hline Perceived value & $\rightarrow$ & b2 & $0.756^{*}$ & 0.111 & 9.599 & 0.311 & 0.572 \\
\hline Perceived value & $->$ & b3 & 0.621 * & 0.116 & 8.559 & 0.575 & 0.385 \\
\hline Perceived value & $->$ & $\mathrm{b} 4$ & 0.769 * & 0.103 & 9.667 & 0.250 & 0.592 \\
\hline Purchase intention & $->$ & $\mathrm{c} 1$ & 0.790 * & 0.126 & 8.262 & 0.234 & 0.623 \\
\hline Purchase intention & $\rightarrow$ & c2 & $0.803 *$ & 0.153 & 8.508 & 0.332 & 0.645 \\
\hline Purchase intention & $->$ & c3 & 0.850 * & 0.140 & 8.390 & 0.190 & 0.723 \\
\hline Involvement degree & $->$ & Perceived value & 0.930 * & 0.270 & 9.363 & $0.049^{1}$ & $0.864^{3}$ \\
\hline Involvement degree & $\rightarrow$ & Purchase intention & 0.028 & 0.391 & 0.192 & \multirow{2}{*}{$0.054^{2}$} & \multirow{2}{*}{$0.860^{3}$} \\
\hline Perceived value & $\rightarrow$ & Purchase intention & 0.901 * & 0.198 & 4.476 & & \\
\hline
\end{tabular}

${ }^{*}$ means it is significant at $0.05 .{ }^{1}:$ The structural error of perceived value. ${ }^{2}$ : The structural error of purchase intention. ${ }^{3}$ : The ability of independent variables to explain dependent variables $\left(R^{2}\right)$. 


\subsection{Verification of Impact Effect}

Perceived value has a positive direct effect on purchase intention, and its effect value is 0.901; the involvement degree has an indirect positive effect on purchase intention through perceived value, and its total effect is 0.866 ; the involvement degree has a positive direct effect on perceived value, and its effect value is 0.930 .

The above analysis results show that:

Hypothesis 5. Involvement degree has no significant positive impact on purchase intention.

Hypothesis 6. Perceived value has a significant positive impact on purchase intention.

Hypothesis 7. Involvement degree has a significant positive impact on perceived value.

Hypothesis 8. Involvement degree has a significant indirect and positive impact on purchase intention through perceived value.

It can be analyzed from the above tests that perceived value plays a significant mediating role between involvement degree and purchase intention, and the mediating effect is a full mediation. Refer to the influence effects in Table 9.

Table 9. Influence Effects.

\begin{tabular}{cccccc}
\hline $\begin{array}{c}\text { Latent Independent } \\
\text { Variable }\end{array}$ & $\begin{array}{c}\text { Latent Dependent } \\
\text { Variable }\end{array}$ & $\begin{array}{c}\text { Direct } \\
\text { Effect }\end{array}$ & Indirect Effect & Overall Effect & $\begin{array}{c}\text { Is the Hypothesis } \\
\text { Established }\end{array}$ \\
\cline { 1 - 5 } Involvement degree & Purchase intention & 0.028 & $0.838^{*}(0.930 * 0.901)$ & 0.866 & $\begin{array}{c}\text { H1 is not established } \\
\text { H4 is established }\end{array}$ \\
\cline { 4 - 7 } Perceived value & & $0.901 *$ & - & 0.901 & H4 is established \\
\hline Involvement degree & Perceived value & 0.930 & - & 0.930 & H4 is established \\
\hline
\end{tabular}

${ }^{*}$ is significant when it is 0.05 ; - means there is no such effect.

\section{Discussion}

\subsection{Key Elements and Suggestions for Unpacked Stores Provided by Experts}

Unpacked stores are different from general stores in that they have different product attributes and advocate environmental protection. These stores do not offer plastic packaging products, and consumers are encouraged to bring their own bags and containers to store their purchases. Many unpacked stores price consumer goods according to weight, providing another emerging consumption model and incorporating the feeling of experience elements [46,47]. Consumers hope that the quality of goods is guaranteed and excellent and that unpacked stores give them more product options and allow them to buy only the amount they need. However, at present, unpacked stores are not universal and comprehensive throughout the world. The main problems include the difficulty in competing with general supermarkets' product prices. Meanwhile, consumers' ideas of buying products for ecological conservation are only a way to purchase products, and they do not necessarily have substantial psychological value or behavior to implement sustainability. Therefore, the government and private organizations must formulate relevant methods to promote more characteristics and philosophy of unpacked stores [48-50].

In the future, the promotion elements of unpacked stores should be diversified goods for consumers to choose from. Consumers should be given the freedom to decide to purchase the quantity, and the cost of the container should be converted into a discounted price. They should also be encouraged to bring their own containers. Further, the products sold must be accompanied by an inspection report. The idea of unpacked consumption can be promoted through the Internet, education, or lectures, starting with developing small supermarkets in the community. If the ecological conservation policy is introduced, it will 
be beneficial to promote unpacked stores in the future, allowing consumers to change and improve their moods by buying in unpacked stores $[25,31,35]$.

\subsection{Impact of Involvement Degree on Consumers' Purchase Intentions}

The involvement degree does not directly affect purchase intention. However, it significantly affects purchase intention through perceived value. In addition, the involvement degree itself has a direct and significant impact on the perceived value. Therefore, it can be found that the involvement degree is based on the combination of involvement with products, involvement with advertisements, and involvement with purchase decisions proposed by Zaichkowsky [32]. Further, perceived value can be divided into emotional value, quality value, social value, and price value, according to Sweeney and Soutar [35]. Hence, the three dimensions of involvement degree will indirectly affect consumers' purchase intentions through the four dimensions of perceived value. Perceived value plays a mediating role between the involvement degree and purchase intention. In the future, the promotion of products can affect consumers' purchase intentions via subjective perception, product quality, image, and price through video and audio advertisements supporting promotional behaviors [24].

\subsection{Impact of Perceived Value on Consumers' Purchase Intentions}

Perceived value has a positive relationship with purchase intention, which means that the higher the emotional, quality, social, and price values, the higher the purchase intention. The factor load is the emotional value $(0.925)>$ price quality $(0.769)>$ quality price $(0.756)>$ social value $(0.621)$. This result means that the first consumers who will buy at unpacked stores care about the overall perception of unpacked stores-whether the shopping pleasure can be satisfied by sustainable behavior, and whether the price is affordable, whether the quality is good, and whether their own behavior is approved by the social perception [24]. In the future, the promotion conditions of unpacked stores for consumers can be determined in terms of the involvement degree and perceived value, which may serve as the reference standards and basis for the unpacked store industry.

\subsection{Limitations}

The subjects of this research were limited to adult consumers in Taiwan who were over 18 years old. Taiwan courts deem people over 18 years old to have full capacity to control their behavior, which means they have mature purchasing thinking skills and are more economically viable. Therefore, the subjects of this research were consumers over 18 years of age, and the questionnaires were distributed in the form of online questionnaires.

\subsection{Recommendations}

It is suggested that future research can explore different specific groups or regions to make this topic more comprehensive, compare differences, and make in-depth analyses in terms of groups and regions. It is hoped to improve consumers' attention to ecological destruction and resource waste to enable the future to move towards the development of a circular and green economy $[1,3]$.

\section{Conclusions}

This research used structural equation modeling (SEM) to verify the model of consumers' purchase intentions in unpacked stores through the involvement degree and perceived value. It combined the grounded theory of expert interviews to extract open interpretations to understand the relevant dimensions affecting the consumption of unpacked stores and extract the key factors for promoting unpacked stores in the future.

Experts of unpacked stores and the surrounding research area suggested that the key factors for promoting unpacked stores include diversified products for consumers to choose from, consumers' freedom to choose according to their own demand, promoting unpacked 
consumption through education and lectures, and developing small supermarkets in the community.

In the model verification results, the involvement degree (including involvement with products, involvement with advertisements, and involvement with purchase intention indirectly) significantly affected purchase intention through perceived value. Meanwhile, perceived value (including emotional, quality, social, and price values) significantly affected purchase intention, with emotional value as the key factor. Consequently, it can be seen that the key to consumers' purchase intention lies in their own cognition and feelings of unpacked products. In the future, the cultivation of consumers' unpacked thinking should be deepened. Other value influences were also strong - in the order of price value, quality value, and social value-which means consumers are also conscious of price and quality as the purchasing criteria. Further, the involvement degree had a direct and significant impact on perceived value, indicating a relationship between the two.

This research aimed to improve people's sustainable psychological values through the topic of unpacked stores. Simultaneously, it conceived methods to reduce the environmental impact under the circular economy to maintain a good state of symbiosis with the ecology, which will serve as a reference direction and criterion for promoting the unpacked store industry in the future.

Author Contributions: Data curation, T.-Y.L. and Y.-J.S.; investigation, Y.-J.S.; methodology, T.-Y.L. and Y.-J.S.; project administration, J.-C.T. and T.-Y.L.; software, T.-Y.L. and Y.-J.S.; supervision, J.-C.T.; writing —original draft preparation, T.-Y.L.; writing—review and editing, J.-C.T., T.-F.K. and T.-Y.L. All authors have read and agreed to the published version of the manuscript.

Funding: This research received no external funding.

Institutional Review Board Statement: About ethical considerations, we would like to mention that all the participants in our experiments are normal adults. Our research is mainly to evaluate the promotion of unpacked stores and the satisfiability to the participants without touching the personal privacy issue. Before conducting the experiments, each participant was informed orally by our research assistants that his/her involvement was voluntary, that anonymity would be guaranteed, and that they may withdraw from the experiment at any time. Therefore, ethical review and approval were waived for this study, due to the above reason.

Informed Consent Statement: Written informed consent has been obtained from the patients to publish this paper.

Acknowledgments: The researchers are grateful for the help of the students of National Yunlin University of Science and Technology and Chao-Ming Wang from the Department of Digital Media Design of National Yunlin University of Science and Technology.

Conflicts of Interest: The authors declare no conflict of interest.

\section{References}

1. Hahladakis, J.N.; Iacovidou, E. Closing the loop on plastic packaging materials: What is quality and how does it affect their circularity? Sci. Total Environ. 2018, 630, 1394-1400. [CrossRef] [PubMed]

2. Broom, D. Peak plastic: The proliferation of plastic. ReNew Technol. A Sustain. Future 2015, 133, $62-67$.

3. Byun, Y.; Kim, Y.T. Utilization of Bioplastics for Food Packaging Industry Innovations in Food Packaging; Elsevier Ltd.: Amsterdam, The Netherlands, 2014; pp. 369-390.

4. Faraca, G.; Astrup, T. Plastic waste from recycling centres: Characterisation and evaluation of plastic recyclability. Waste Manag. 2019, 95, 388-398. [CrossRef] [PubMed]

5. Hahladakis, J.N.; Purnell, P.; Iacovidou, E.; Velis, C.A.; Atseyinku, M. Post-consumer plastic packaging waste in England: Assessing the yield of multiple collection-recycling schemes. Waste Manag. 2018, 75, 149-159. [CrossRef] [PubMed]

6. Salkova, D.; Regnerova, O. Methods of eliminating waste from food packaging as a globalization tool. SHS Web Conf. 2020, 74, 4025. [CrossRef]

7. Šuput, D.; Popović, S.; Hromiš, N.; Ugarković, J. Possibilities and Application of Degradable Packaging Materials. Inoptep 2021, 2021, 43.

8. Van Herpen, E.; Immink, V.; Van Den Puttelaar, J. Organics unpacked: The influence of packaging on the choice for organic fruits and vegetables. Food Qual. Prefer. 2016, 53, 90-96. [CrossRef] 
9. Šuput, D.; Popović, S.; Hromiš, N.; Ugarković, J. Degradable Packaging Materials-sources, Application and Decomposition Routes. J. Process. Energy Agric. 2021, 25, 37-42. [CrossRef]

10. Brouwer, M.T.; van Velzen, E.U.T.; Augustinus, A.; Soethoudt, H.; De Meester, S.; Ragaert, K. Predictive model for the Dutch postconsumer plastic packaging recycling system and implications for the circular economy. Waste Manag. 2018, 71, 62-85. [CrossRef]

11. Warrings, R. Circular Economy of Packaging Aluminium: An Analysis of the Current Practice and Future Potential; TU Wien Academic Press: Vienna, Austria, 2020.

12. Tallentire, C.; Steubing, B. The environmental benefits of improving packaging waste collection in Europe. Waste Manag. 2020, 103, 426-436. [CrossRef]

13. Da Cruz, N.F.; Ferreira, S.; Cabral, M.; Simões, P.; Marques, R.C. Packaging waste recycling in Europe: Is the industry paying for it? Waste Manag. 2014, 34, 298-308. [CrossRef]

14. Fråne, A.; Stenmarck, Å.; Gíslason, S.; Lyng, K.-A.; Løkke, S.; Zu Castell-Rüdenhausen, M.; Wahlström, M. Collection E Recycling of Plastic Waste: Improvements in Existing Collection and Recycling Systems in the Nordic Countries; Nordic Council of Ministers: Copenhagen, Denmark, 2014.

15. Van Velzen, E.U.T. Post-Consumer Plastic Packaging Waste-How to Increase the Yield and Reduce the Cost? Waste Manag. 2012, 75, 157-167.

16. Schmidt, S.; Laner, D. The multidimensional effects of single-use and packaging plastic strategies on German household waste management. Waste Manag. 2021, 131, 187-200. [CrossRef]

17. Rigamonti, L.; Ferreira, S.; Grosso, M.; Marques, R.C. Economic-financial analysis of the Italian packaging waste management system from a local authority's perspective. J. Clean. Prod. 2015, 87, 533-541. [CrossRef]

18. Martinho, G.; Gomes, A.; Santos, P.; Ramos, M.; Cardoso, J.; Silveira, A.; Pires, A. A case study of packaging waste collection systems in Portugal-Part I: Performance and operation analysis. Waste Manag. 2017, 61, 96-107. [CrossRef]

19. Brouwer, M.; Picuno, C.; van Velzen, E.U.T.; Kuchta, K.; De Meester, S.; Ragaert, K. The impact of collection portfolio expansion on key performance indicators of the Dutch recycling system for Post-Consumer Plastic Packaging Waste, a comparison between 2014 and 2017. Waste Manag. 2019, 100, 112-121. [CrossRef]

20. Berglund, C. Material Collection of Household Waste and Ongoing Research at the Swedish Epa. Waste Management: Research, Development and Policy; Nova Publishers: Hauppauge, NY, USA, 2008; p. 307.

21. Dahlbo, H.; Poliakova, V.; Mylläri, V.; Sahimaa, O.; Anderson, R. Recycling potential of post-consumer plastic packaging waste in Finland. Waste Manag. 2018, 71, 52-61. [CrossRef]

22. Oelofse, S.H. Recycling in SA-How Does the National Domestic Waste Collection Standards Affect Consumers; CSIR: Pretoria, South Africa, 2011.

23. Loučanová, E. Perception of Zero Waste in the Context to Environmental Innovation in Slovakia. Studia Univ. Vasile Goldiş Arad-Ser. Ştiinţe Econ. 2021, 31, 22-33. [CrossRef]

24. Teas, R.K.; Agarwal, S. The effects of extrinsic product cues on consumers' perceptions of quality, sacrifice, and value. J. Acad. Mark. Sci. 2000, 28, 278-290. [CrossRef]

25. Schiffman, L.G.; Kanuk, L.L.; Wisenblit, J. Consumer Behavior; J: Prentice Hall: Upper Saddle River, NJ, USA, 2000.

26. Kotler, P.; Dubois, B. Marketing Management, 11st ed.; Pearson Education: Upper Saddle River, NJ, USA, 2003.

27. Greenwald, A.G.; Leavitt, C. Audience involvement in advertising: Four levels. J. Consum. Res. 1984, 11, 581-592. [CrossRef]

28. Monroe, K.B.; Krishnan, R. The effect of price on subjective product evaluations. Perceived Qual. 1985, 1, $209-232$.

29. Garretson, J.A.; Clow, K.E. The influence of coupon face value on service quality expectations, risk perceptions and purchase intentions in the dental industry. J. Serv. Mark. 1999, 13, 59-72. [CrossRef]

30. Permarupan, P.Y.; Mohan, M.; Al-Mamun, A.; Zainol, N.R.B. Consumer perceived value and buying behavior of store brands. Int Bus. Manag. 2014, 8, 136-141.

31. Diallo, M.F. Effects of store image and store brand price-image on store brand purchase intention: Application to an emerging market. J. Retail. Consum. Serv. 2012, 19, 360-367. [CrossRef]

32. Zaichkowsky, J.L. Measuring the involvement construct. J. Consum. Res. 1985, 12, 341-352. [CrossRef]

33. Dahlén, L.; Lagerkvist, A. Methods for household waste composition studies. Waste Manag. 2008, 28, 1100-1112. [CrossRef]

34. Zaichkowsky, J.L. The personal involvement inventory: Reduction, revision, and application to advertising. J. Advert. 1994, 23, 59-70. [CrossRef]

35. Sweeney, J.C.; Soutar, G.N. Consumer perceived value: The development of a multiple item scale. J. Retail. 2001, 77, 203-220. [CrossRef]

36. Van Velzen, E.T.; Brouwer, M.; Feil, A. Collection behaviour of lightweight packaging waste by individual households and implications for the analysis of collection schemes. Waste Manag. 2019, 89, 284-293. [CrossRef]

37. Davis, G.; Song, J. Biodegradable packaging based on raw materials from crops and their impact on waste management. Ind. Crop. Prod. 2006, 23, 147-161. [CrossRef]

38. Edjabou, M.E.; Takou, V.; Boldrin, A.; Petersen, C.; Astrup, T.F. The influence of recycling schemes on the composition and generation of municipal solid waste. J. Clean. Prod. 2021, 295, 126439. [CrossRef]

39. Henriksson, G.; Åkesson, L.; Ewert, S. Uncertainty regarding waste handling in everyday life. Sustainability 2010, 2, 2799-2813. [CrossRef] 
40. Edjabou, M.E.; Jensen, M.B.; Götze, R.; Pivnenko, K.; Petersen, C.; Scheutz, C.; Astrup, T.F. Municipal solid waste composition: Sampling methodology, statistical analyses, and case study evaluation. Waste Manag. 2015, 36, 12-23. [CrossRef] [PubMed]

41. Hair Junior, J.F.; Black, W.C.; Babin, B.J.; Anderson, R.E.; Tatham, R.L. Multivariate Data Analysis; Pearson Education: Upper Saddle River, NJ, USA, 1998.

42. Browne, M.W. Asymptotically distribution-free methods for the analysis of covariance structures. Br. J. Math. Stat. Psychol. 1984, 37, 62-83. [CrossRef] [PubMed]

43. Bollen, K.A.; Long, J.S. Testing Structural Equation Models; SAGE Publications, Inc.: New York, NY, USA, 1993.

44. Mardia, K.V.; Foster, K. Omnibus tests of multinormality based on skewness and kurtosis. Commun. Stat.-Theory Methods 1983, 12, 207-221. [CrossRef]

45. Raykov, T.; Marcoulides, G.A. An Introduction to Applied Multivariate Analysis; Routledge: Milton Park, UK, 2008.

46. Barr, S.; Gilg, A. Sustainable lifestyles: Framing environmental action in and around the home. Geoforum 2006, 37, 906-920. [CrossRef]

47. Sharp, V.; Giorgi, S.; Wilson, D.C. Delivery and impact of household waste prevention intervention campaigns (at the local level). Waste Manag. Res. 2010, 28, 256-268. [CrossRef]

48. Boz, Z.; Korhonen, V.; Koelsch Sand, C. Consumer considerations for the implementation of sustainable packaging: A review. Sustainability 2020, 12, 2192. [CrossRef]

49. Chinie, A.-C. Challenges for reducing food waste. In Proceedings of the International Conference on Business Excellence, Bucharest, Romania, 22-23 March 2018; pp. 819-828.

50. Jánošová, P. Sustainable activities in manufacturing enterprises: Consumers' expectations. Upravlenec 2021, 12, 91-101. [CrossRef] 